Article

\title{
Assignment of the CD Cotton Effect to the Chiral Center in Pseurotins, and the Stereochemical Revision of Pseurotin $\mathrm{A}_{2}$
}

\author{
Takeshi Yamada *, Mina Ohshima, Kaori Yuasa, Takashi Kikuchi and Reiko Tanaka \\ Medicinal Chemistry Laboratory, Osaka University of Pharmaceutical Sciences, 4-20-1, Nasahara, Takatsuki, \\ Osaka 569-1094, Japan; skr-dh.mc-tp.128@ezweb.ne.jp (M.O.); k.m.k.l.v.k@gmail.com (K.Y.); \\ t.kikuchi@gly.oups.ac.jp (T.K.); tanakar@gly.oups.ac.jp (R.T.) \\ * Correspondence: yamada@gly.oups.ac.jp; Tel.: +81-726-90-1085; Fax: +81-726-90-1084 \\ Academic Editor: Anake Kijjoa \\ Received: 3 February 2016; Accepted: 31 March 2016; Published: 9 April 2016
}

\begin{abstract}
Pseurotins $A_{1}(1)$ and $A_{2}$ (2) were isolated from a culture broth of the fungal strain Aspergillus fumigatus WFZ-25 as stereoisomers of pseurotin A (3) in 2011. We also isolated $\mathbf{1}$ and $\mathbf{2}$ together with 3 from A. fumigatus OUPS-T106B-5 separated from the marine fish Mugil cephalus. In this study, we re-examined the stereochemistry of $\mathbf{1}$ and $\mathbf{2}$ using chemical transformation and the $\mathrm{CD}$ spectra, and found the relationship between the CD Cotton effect and the absolute configurations of 1 and 2, which led us to revise the stereostructure of pseurotin $\mathrm{A}_{2}$.
\end{abstract}

Keywords: pseurotins; Aspergillus fumigatus; marine microorganism; marine fish; cephalimysins; spiro-heterocyclic $\gamma$-lactam

\section{Introduction}

Pseurotin A (3) is a major secondary metabolite isolated from the fungal strains Pseudeurotium ovalis and Aspergillus fumigatus, and it has an unusual structure containing a spiro-heterocyclic $\gamma$-lactam core [1-4]. Its absolute configuration was determined by X-ray diffraction analysis of a dibromo derivative [1]. Most of the other $\gamma$-lactams were determined by asymmetric total synthesis [5-10] and the modified Mosher's method [11,12]. Previously, we reported that all stereoisomers of FD-838 showed an association between the CD Cotton effect and the absolute configuration of the chiral centers in $\gamma$-lactam [13]. Meanwhile, stereoisomers of pseurotin A designated as pseurotins $\mathrm{A}_{1}(\mathbf{1})$ and $\mathrm{A}_{2}$ (2) were isolated from a culture broth of the fungal strain Aspergillus fumigatus WFZ-25 by Q.Q. Gu and co-researchers [14]. The absolute stereostructures of $\mathbf{1}$ and $\mathbf{2}$ were elucidated by NOESY experiments and comparison with the $\mathrm{CD}$ data pattern in the above report [14]. We herein report our re-examination of the absolute configurations of $\mathbf{1}$ and $\mathbf{2}$ using chemical transformation, measurement of the ${ }^{1} \mathrm{H}-\mathrm{NMR}$ coupling constant, and CD spectra. In addition, we describe our revision of the stereochemistry of 2 .

\section{Results and Discussion}

Fractionation of an ethyl acetate extract of the culture broth of A. fumigatus OUPS-T106B-5 was conducted as reported previously [12,13], employing a stepwise combination of Sephadex LH-20 and silica gel column chromatographies, followed by reverse-phase HPLC, to yield pseurotins $A_{1}(\mathbf{1}), A_{2}$ (2) and A (3) (Figure 1). 


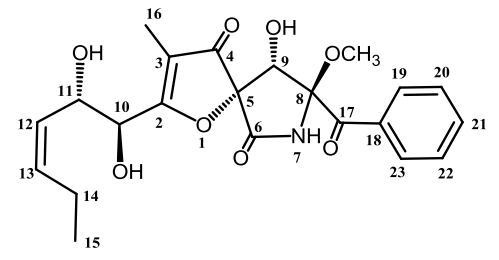

1: pseurotin $A_{1}$

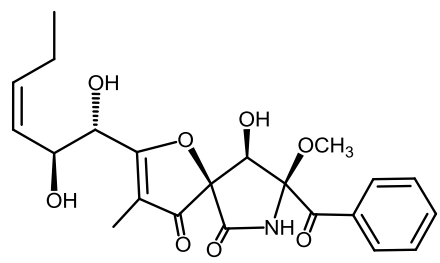

4: revised structureof pseurotin $\mathrm{A}_{2}$

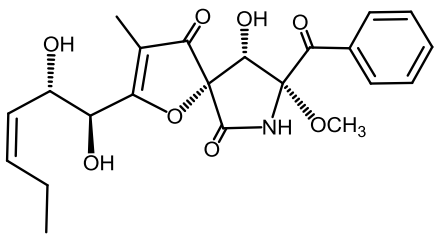

2: reported structure of pseurotin $A_{2}$

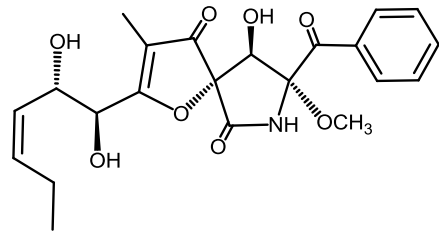

5: reaction product 8 -epimer of $\mathbf{3}$

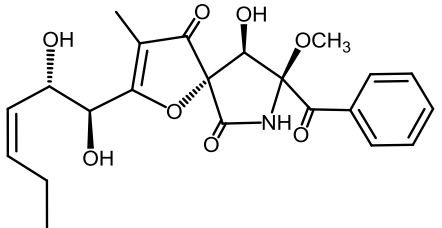

3: pseurotin A

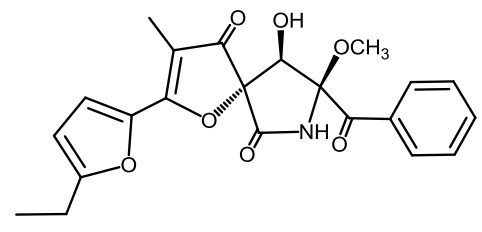

FD-838

Figure 1. Structures of pseurotins and FD-838.

Pseurotin $\mathrm{A}_{1}(\mathbf{1})$ had the molecular formula $\mathrm{C}_{22} \mathrm{H}_{25} \mathrm{NO}_{8}$, as established from the $[\mathrm{M}+\mathrm{Na}]^{+}$peak in high resolution fast atom bombardment mass spectrometry (HRFABMS). A close inspection of the ${ }^{1} \mathrm{H}$ - and ${ }^{13} \mathrm{C}-\mathrm{NMR}$ spectra of $\mathbf{1}$ (Table 1, Supplementary Material Figures S1 and S2) using DEPT and ${ }^{1} \mathrm{H}-{ }^{13} \mathrm{C}$ correlation spectroscopy (HMQC) revealed the presence of one primary methyl (C-15), one olefinic methyl (C-16), one methoxy group $\left(8-\mathrm{OCH}_{3}\right)$, one $\mathrm{sp}^{3}$-hybridized methylene $(\mathrm{C}-14)$, three oxygen-bearing $\mathrm{sp}^{3}$-methines (C-9, C-10 and C-11), two olefin $\mathrm{sp}^{2}$-methines (C-12 and C-13), two oxygen-bearing quaternary sp ${ }^{3}$-carbons $(\mathrm{C}-5$ and $\mathrm{C}-8)$, five aromatic protons (C-19, C-20, C-21, C-22 and C-23), three quaternary $\mathrm{sp}^{2}$-carbons $(\mathrm{C}-2, \mathrm{C}-3, \mathrm{C}-18)$ including one oxygen-bearing quaternary carbons (C-2), two conjugated carbonyl groups (C-4 and C-17), one amido (C-6 and N-7) and one hydroxy group (9-OH). The connection of these units was determined on the basis of ${ }^{1} \mathrm{H}-{ }^{1} \mathrm{H}$ COSY and $\mathrm{HMBC}$ correlations to reveal the planar structure of $\mathbf{1}$, which was identified as being the same as that of pseurotin $A_{1}$ by comparison with data in the literature [14]. In addition, spectroscopic analyses of 2 and 3 identified them as pseurotin $\mathrm{A}_{2}$ and pseurotin A, respectively [14] (Supplementary Material Figures S3-S10).

We succeeded in the isolation of all stereoisomers of FD-838 (Figure 1) including four reaction products, and, therefore, we could establish the relationship between absolute configurations at C-5 and $\mathrm{C}-8$ in the spirofuranone-lactam skeleton and the CD Cotton effects. In addition, we found that the chemical shifts of $\mathrm{H}-9$ and the coupling constant between $\mathrm{H}-9$ and $9-\mathrm{OH}$ in the ${ }^{1} \mathrm{H}-\mathrm{NMR}$ spectrum with $\mathrm{CDCl}_{3}$ as a solvent demonstrated the orientations of 9-OH and 8- $-\mathrm{OCH}_{3}$ [13]. On investigating the absolute configuration for pseurotin $\mathrm{A}_{1}$ (1) [14], we applied the above phenomena. Comparing the $\mathrm{CD}$ spectral data of $\mathbf{1}$ and $\mathbf{3}$, the similarity of their CD curves showed that the absolute configurations of $C-5$ and $C-8$ in $\mathbf{1}$ were the same as those in 3 , i.e., $\mathbf{1}$ possessed the $5 S, 8 S$ absolute configuration (Figure 2A). For the absolute configuration at $\mathrm{C}-9,9-\mathrm{OH}$ oriented cis to $8-\mathrm{OCH}_{3}$ for a large coupling constant $(J=12 \mathrm{~Hz})$, and trans to $8-\mathrm{OCH}_{3}$ for a small coupling constant $(J=4 \mathrm{~Hz})$ in its ${ }^{1} \mathrm{H}-\mathrm{NMR}$ spectra, and the relative configuration between $9-\mathrm{OH}$ and $8-\mathrm{OCH}_{3}$ regularly influenced the chemical shift of C-9 in its ${ }^{13} \mathrm{C}-\mathrm{NMR}$ spectra [13]. In this study, we could not observe the coupling constant between $\mathrm{H}-9$ and 9-OH (vide info); however, the NMR chemical shifts of $\mathrm{C}-9\left(\delta_{C} 76.6\right)$ clearly showed that 9-OH oriented trans to $8-\mathrm{OCH}_{3}$ [13]. If 9-OH orients cis to 8- $\mathrm{OCH}_{3}$, the $\mathrm{NMR}$ chemical shifts of C-9 would be observed in a high field $\left(\delta_{C} \sim 74.0\right)$ [13]. The above evidence confirmed the absolute stereostructure of $\mathbf{1}$ [14]. Q.Q. Gu and co-researchers determined the stereochemistry of $\mathbf{1}$ from NOESY correlations $\left(\mathrm{H}-9 / 8-\mathrm{OCH}_{3}\right.$ and $\left.9-\mathrm{OH} / 10-\mathrm{OH}\right)$ and a comparison of the $\mathrm{CD}$ data with 3 . In addition, they had referred to our $\mathrm{CD}$ spectral examination; however, they had not confirmed the wavelength of the maximum absorbance proceeding from a chiral center of C-8 $[13,14]$. 
Table 1. NMR spectral data forpseurotins in $\mathrm{CDCl}_{3}$.

\begin{tabular}{|c|c|c|c|c|c|c|c|c|c|c|c|c|c|c|c|c|}
\hline \multirow{2}{*}{ Position } & \multicolumn{4}{|c|}{ Pseurotin $A_{1}$ (1) } & \multicolumn{4}{|c|}{ Pseurotin $A_{2}$} & \multicolumn{4}{|c|}{3} & \multicolumn{4}{|c|}{5} \\
\hline & $\delta_{H}{ }^{a}$ & $\mathrm{~m}, J / \mathrm{Hz}$ & $\delta_{c}$ & & $\delta_{\mathrm{H}}{ }^{\mathrm{a}}$ & $\mathrm{m}, J / \mathrm{Hz}$ & $\delta_{c}$ & & $\delta_{\mathrm{H}}{ }^{\mathrm{a}}$ & $\mathrm{m}, J / \mathrm{Hz}$ & $\delta_{C}$ & & $\delta_{\mathrm{H}}{ }^{\mathrm{a}}$ & $\mathrm{m}, J / \mathrm{Hz}$ & $\delta_{C}$ & \\
\hline 1 & & & & & & & & & & & & & & & & \\
\hline 2 & & & 183.4 & $\mathrm{qC}$ & & & 183.5 & $\mathrm{qC}$ & & & 186.0 & $\mathrm{qC}$ & & & 186.4, & $\mathrm{qC}$ \\
\hline 3 & & & 113.2 & $\mathrm{qC}$ & & & 114.3 & $\mathrm{qC}$ & & & 113.4 & $\mathrm{qC}$ & & & 114.8 & $\mathrm{qC}$ \\
\hline 4 & & & 196.2 & $\mathrm{qC}$ & & & 199.7 & $\mathrm{qC}$ & & & 196.5 & $\mathrm{qC}$ & & & 201.1, & $\mathrm{qC}$ \\
\hline 5 & & & 89.5 & $\mathrm{qC}$ & & & 87.3 & $\mathrm{qC}$ & & & 92.7 & $\mathrm{qC}$ & & & 86.5 & $\mathrm{qC}$ \\
\hline 6 & & & 169.4 & $\mathrm{qC}$ & & & 166.9 & $\mathrm{qC}$ & & & 166.8 & $\mathrm{qC}$ & & & 167.5, & $\mathrm{qC}$ \\
\hline 7 & 8.53 & $\mathrm{~s}$ & & & 7.70 & $\mathrm{~s}$ & & & 8.38 & $\mathrm{~s}$ & & & 7.34 & $\mathrm{~s}$ & & \\
\hline 8 & & & 96.5 & $\mathrm{qC}$ & & & 93.2 & $\mathrm{qC}$ & & & 90.5 & $\mathrm{qC}$ & & & 96.4 & $\mathrm{qC}$ \\
\hline 9 & 4.88 & s & 76.6 & $\mathrm{CH}$ & 4.42 & br d, $12.0(9-\mathrm{OH})$ & 74.2 & $\mathrm{CH}$ & 4.69 & brs & 73.2 & $\mathrm{CH}$ & 4.86 & d, $5.4(9-\mathrm{OH})$ & 78.6 & $\mathrm{CH}$ \\
\hline 10 & 4.60 & brs & 70.5 & $\mathrm{CH}$ & 4.73 & $\mathrm{~d}, 3.0(11)$ & 70.1 & $\mathrm{CH}$ & 4.59 & $\mathrm{~d}, 5.4(11)$ & 70.7 & $\mathrm{CH}$ & 4.69 & br d, $5.4(11)$ & 70.9 & $\mathrm{CH}$ \\
\hline 11 & 4.76 & $\mathrm{~d}, 7.8(12)$ & 71.0 & $\mathrm{CH}$ & 4.94 & $\begin{array}{c}\text { dd, } \\
8.4(12) 3.0(10)\end{array}$ & 70.6 & $\mathrm{CH}$ & 4.75 & $\begin{array}{c}\mathrm{dd}, \\
10.8(12) 5.4(10)\end{array}$ & 70.7 & $\mathrm{CH}$ & 4.81 & $\begin{array}{c}\mathrm{dd}, \\
10.8(12) 5.4(10)\end{array}$ & 69.6, & $\mathrm{CH}$ \\
\hline 12 & 5.23 & $\begin{array}{c}\mathrm{dd}, \\
10.8(13) 7.8(11)\end{array}$ & 126.4 & $\mathrm{CH}$ & 5.28 & $\begin{array}{c}\mathrm{dd}, \\
10.8(13) 8.4(11)\end{array}$ & 125.3 & $\mathrm{CH}$ & 5.28 & $\begin{array}{c}\mathrm{dd}, \\
11.2(13) 10.8 \text { (11) }\end{array}$ & 126.4 & $\mathrm{CH}$ & 5.43 & $\begin{array}{c}\mathrm{dd}, \\
11.2(13) 10.8(11)\end{array}$ & 125.6, & $\mathrm{CH}$ \\
\hline 13 & 5.64 & $\begin{array}{c}\mathrm{dt}, \\
10.8(12) 7.2(14)\end{array}$ & 136.9 & $\mathrm{CH}$ & 5.64 & $\begin{array}{c}\mathrm{dt}, \\
10.8(12) 7.2(14)\end{array}$ & 137.4 & $\mathrm{CH}$ & 5.59 & $\begin{array}{c}\mathrm{dt} \\
11.2(12) 7.8(14)\end{array}$ & 136.8 & $\mathrm{CH}$ & 5.74 & $\begin{array}{c}\mathrm{dt}, \\
11.2(12) 7.8(14)\end{array}$ & 138.2 & $\mathrm{CH}$ \\
\hline $14 \mathrm{~A}$ & 2.09 & $\mathrm{~m}$ & 21.4 & $\mathrm{CH}_{2}$ & 2.14 & $\mathrm{~m}$ & 21.4 & $\mathrm{CH}_{2}$ & 2.09 & $\mathrm{~m}$ & 21.4 & $\mathrm{CH}_{2}$ & 2.15 & $\mathrm{~m}$ & 21.5, & $\mathrm{CH}_{2}$ \\
\hline $14 \mathrm{~B}$ & 2.15 & $\mathrm{~m}$ & & & 2.19 & $\mathrm{~m}$ & & & 2.15 & $\mathrm{~m}$ & & & 2.21 & $\mathrm{~m}$ & & \\
\hline 15 & 0.99 & $\mathrm{t}, 7.8(14)$ & 14.1 & $\mathrm{CH}_{3}$ & 1.03 & $\mathrm{t}, 7.2(14)$ & 14.1 & $\mathrm{CH}_{3}$ & 0.98 & $\mathrm{t}, 9.0(14)$ & 14.1 & $\mathrm{CH}_{3}$ & 1.05 & $\mathrm{t}, 7.2(14)$ & 14.2, & $\mathrm{CH}_{3}$ \\
\hline 16 & 1.68 & $\mathrm{~s}$ & 6.2 & $\mathrm{CH}_{3}$ & 1.67 & $\mathrm{~s}$ & 5.9 & $\mathrm{CH}_{3}$ & 1.68 & $\mathrm{~s}$ & 6.0 & $\mathrm{CH}_{3}$ & 1.78 & $\mathrm{~s}$ & 5.6, & $\mathrm{CH}_{3}$ \\
\hline 17 & & & 194.3 & $\mathrm{qC}$ & & & 194.0 & $\mathrm{qC}$ & & & 195.2 & $\mathrm{qC}$ & & & 192.4, & $\mathrm{qC}$ \\
\hline 18 & & & 133.5 & $\mathrm{qC}$ & & & 132.8 & $\mathrm{qC}$ & & & 132.4 & $\mathrm{qC}$ & & & 133.8 & $\mathrm{qC}$ \\
\hline 19 & 8.27 & d, $8.4(20)$ & 130.0 & $\mathrm{CH}$ & 8.34 & d, $8.4(20)$ & 130.7 & $\mathrm{CH}$ & 8.31 & d, $8.4(20)$ & 130.7 & $\mathrm{CH}$ & 8.20 & d, $8.4(20)$ & 129.4, & $\mathrm{CH}$ \\
\hline 20 & 7.49 & $\mathrm{t}, 8.4(19,21)$ & 128.8 & $\mathrm{CH}$ & 7.48 & $\mathrm{t}, 8.4(19,21)$ & 128.6 & $\mathrm{CH}$ & 7.49 & $\mathrm{t}, 8.4(19,21)$ & 128.7 & $\mathrm{CH}$ & 7.50 & $\mathrm{t}, 8.4(19,21)$ & 128.8 & $\mathrm{CH}$ \\
\hline 21 & 7.64 & $\mathrm{t}, 8.4(20,22)$ & 134.4 & $\mathrm{CH}$ & 7.63 & $\mathrm{t}, 8.4(20,22)$ & 134.6 & $\mathrm{CH}$ & 7.64 & $\mathrm{t}, 8.4(20,22)$ & 134.7 & $\mathrm{CH}$ & 7.63 & $\mathrm{t}, 8.4(20,22)$ & 134.2 & $\mathrm{CH}$ \\
\hline 22 & 7.49 & $\mathrm{t}, 8.4(21,23)$ & 128.8 & $\mathrm{CH}$ & 7.48 & $\mathrm{t}, 8.4(21,23)$ & 128.6 & $\mathrm{CH}$ & 7.49 & $\mathrm{t}, 8.4(21,23)$ & 128.7 & $\mathrm{CH}$ & 7.50 & $\mathrm{t}, 8.4(21,23)$ & 128.8 & $\mathrm{CH}$ \\
\hline 23 & 8.27 & $\mathrm{~d}, 8.4(22)$ & 130.0 & $\mathrm{CH}$ & 8.34 & $\mathrm{~d}, 8.4(22)$ & 130.7 & $\mathrm{CH}$ & 8.31 & $\mathrm{~d}, 8.4(22)$ & 130.7 & $\mathrm{CH}$ & 8.20 & $\mathrm{~d}, 8.4(22)$ & 129.4, & $\mathrm{CH}$ \\
\hline $8-\mathrm{OCH}_{3}$ & 3.37 & $\mathrm{~s}$ & 51.7 & $\mathrm{CH}_{3}$ & 3.30 & $\mathrm{~s}$ & 51.9 & $\mathrm{CH}_{3}$ & 3.44 & $\mathrm{~s}$ & 51.8 & $\mathrm{CH}_{3}$ & 3.27 & $\mathrm{~s}$ & 51.5 & $\mathrm{CH}_{3}$ \\
\hline 9-OH & 3.94 & br s & & & 4.22 & br d, 12.0 (9) & & & 4.25 & brs & & & 4.97 & d, $5.4(9)$ & & \\
\hline
\end{tabular}

a ${ }^{1} \mathrm{H}$ chemical shift values ( $\delta$ ppm from $\left.\mathrm{SiMe}_{4}\right)$ followed by multiplicity and then the coupling constants $(J / \mathrm{Hz})$. Figures in parentheses indicate the proton coupling with that position 
The extended conjugate system in pseurotins was less marked than those in FD-838 and cephalimysins B-D; therefore, the Cotton effects in the CD spectra should exhibit a hypsochromic shift [13]. In order to assign the Cotton effect ascribed to the configuration at C-8, we examined the epimerization at C-8 in 3. Treatment of 3 with conc. $\mathrm{H}_{2} \mathrm{SO}_{4}$ in $\mathrm{MeOH}$ gave 5 , an 8-epimer of 3 , as reported in the literature [13] (Supplementary Material Figures S11 and S12). The CD spectrum of 5 showed the opposite curve to that of 3 at around $280 \mathrm{~nm}$ (Figure 2B), i.e., the negative Cotton effect at around $280 \mathrm{~nm}$ demonstrated that the absolute configuration at C-8 was an $S$ configuration.
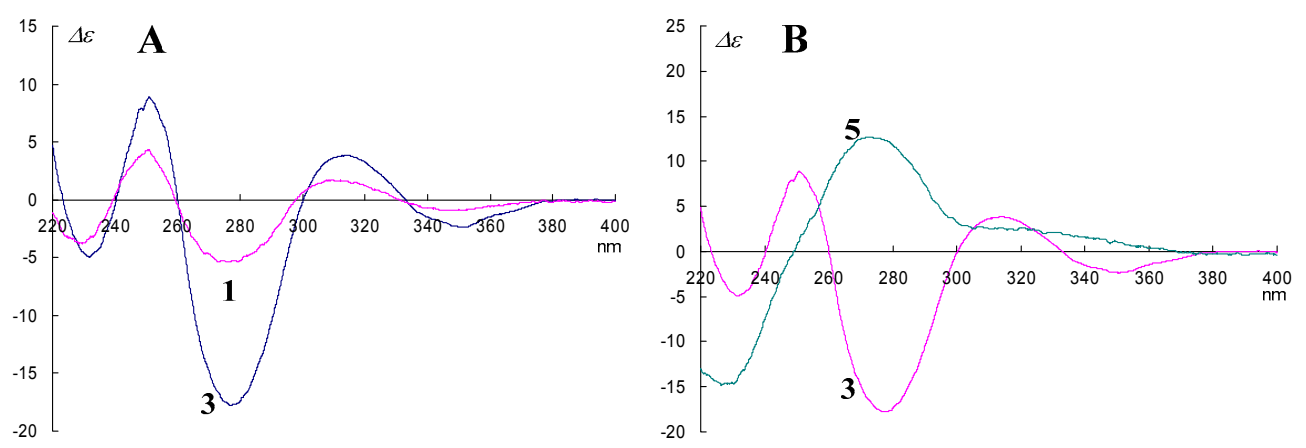

Figure 2. (A) The comparison of CD spectra of $\mathbf{1}$ and 3; (B) The comparison of CD spectra of $\mathbf{3}$ and $\mathbf{5}$.

To confirm the stereostructure of pseurotin $A_{2}$ as 2 [14], a comparison with CD spectral data of pseurotin $A_{2}$ and 3 was carried out. The Cotton effect at around $250 \mathrm{~nm}$ in the CD spectral data of pseurotin $\mathrm{A}_{2}$ was negative, while that of 3 was positive (Figure 3). Q.Q. Gu et al. reported that this difference was due to the change from $8 S$ in 3 to $8 R$ in 2 [14]; however, the above evidence showed that their deduction should be corrected, i.e., the negative Cotton effect $\left(\lambda_{\max } \sim 280 \mathrm{~nm}\right)$ in the CD spectrum of pseurotin $\mathrm{A}_{2}$ revealed that the absolute configuration at $\mathrm{C}-8$ was an $S$ and not $R$ configuration (Figure 3). Meanwhile, the large coupling constant between $\mathrm{H}-9$ and $9-\mathrm{OH}$ in the ${ }^{1} \mathrm{H}-\mathrm{NMR}$ spectrum $(J=12.0 \mathrm{~Hz})$ showed that $9-\mathrm{OH}$ oriented cis to $8-\mathrm{OCH}_{3}$, i.e., the absolute configuration at $\mathrm{C}-9$ was an $R$ configuration [13]. Q.Q. Gu et al. [14] observed a NOESY correlation between 9-OH and 10-OH in 2, while we could not observe it. This NOESY correlation and the above evidence suggested a reversal of the configuration at C-5 in 2; therefore, we found that the CD Cotton effect ascribed to the enone moiety $\left(\lambda_{\max } \sim 250 \mathrm{~nm}\right.$ ) could be assigned to the absolute configuration at C-5. Based on the detailed analysis of the CD spectra of pseurotin $A_{2}$ and 3 , the $5 S$ isomer 3 showed positive $\left(\lambda_{\max } \sim 250 \mathrm{~nm}\right)$ and negative $\left(\lambda_{\max } \sim 230 \mathrm{~nm}\right)$ Cotton effects, while the $5 R$ isomer 2 , pseurotin $A_{2}$, showed negative $\left(\lambda_{\max } \sim 250 \mathrm{~nm}\right)$ and positive $\left(\lambda_{\max } \sim 230 \mathrm{~nm}\right)$ Cotton effects, respectively (Figure 3$)$. We had demonstrated the same relationship as this phenomenon in our previous report [13], i.e., the $5 S$ isomer (FD-838 and cephalimysin B) exhibited a positive Cotton effect, and the $5 R$ isomer (cephalimysin C and D) exhibited a negative Cotton effect at around $350 \mathrm{~nm}$, respectively.

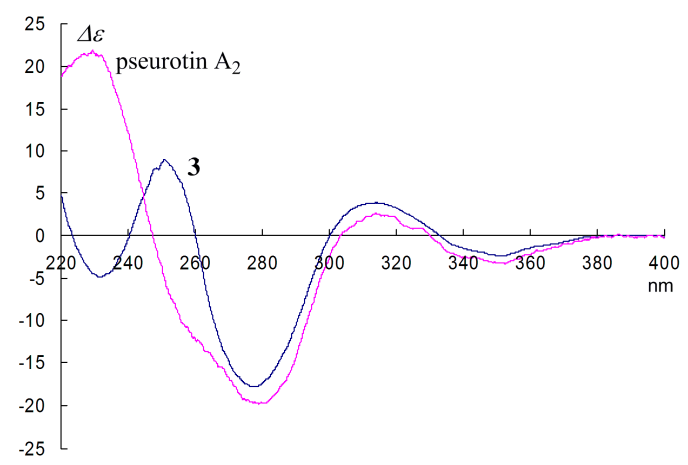

Figure 3. $\mathrm{CD}$ spectra of pseurotin $\mathrm{A}_{2}$ and 3. 
The stereochemistries of C-10 and C-11 in the side chain of pseurotins were not established positively. To build a relative stereochemistry between the spiro $\gamma$-lactam moiety and the side chain, we attempted derivatization to acetonide between $10-\mathrm{OH}$ and $11-\mathrm{OH}$ in 1 . The treatment with 2, 2-dimethoxypropane in $\mathrm{CH}_{2} \mathrm{Cl}_{2}$ yielded acetonide 6 (Supplementary Material Figure S13). Its NOESY correlations (acetonide $\alpha-\mathrm{CH}_{3} / 9-\mathrm{OH}$ and $3-\mathrm{CH}_{3}$, acetonide $\beta-\mathrm{CH}_{3} / \mathrm{H}-10$ and $\mathrm{H}-11$, and $\mathrm{H}-10 / 3-\mathrm{CH}_{3}$ ) clearly showed the absolute conformation of $\mathrm{H}-10$ and $\mathrm{H}-11$ to both be $S$ (Figure $4 \mathrm{~A}$, Supplementary Material Figure S15). When assuming the stereochemistry in the side chain to be reversed, it was inconsistent with the observed NOESY correlations. Therefore, we deduced that the steric vicinity between the acetonide and $3-\mathrm{CH}_{3}$ restrained the free rotation between $\mathrm{C}-2$ and C-10. The NOESY experiment of acetonide 7 (Supplementary Material Figure S14) derived from 4 by the same procedure gave plenty of information for the elucidation of the absolute stereostructure of 4, i.e., NOESY correlations (acetonide $\alpha-\mathrm{CH}_{3} / 9-\mathrm{OH}$ and $8-\mathrm{OCH}_{3}$, acetonide $\beta-\mathrm{CH}_{3} / \mathrm{H}-10$ and $\mathrm{H}-11$, $\mathrm{H}-10 / 3-\mathrm{CH}_{3}$, and $\mathrm{H}-12 / 3-\mathrm{CH}_{3}$ and $\left.9-\mathrm{OH}\right)$ were demonstrated in the $10 \mathrm{~S}, 11 \mathrm{~S}$ absolute configuration (Figure 4B, Supplementary Material Figure S16). Especially, the correlation between $\mathrm{H}-12$ and 9-OH would not be detected in the $10 R, 11 R$ configuration.

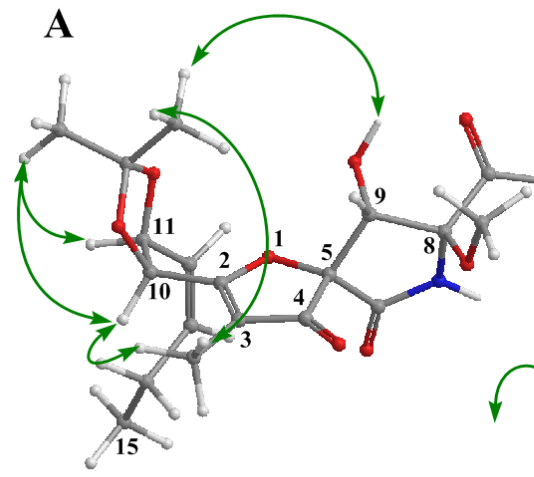

6

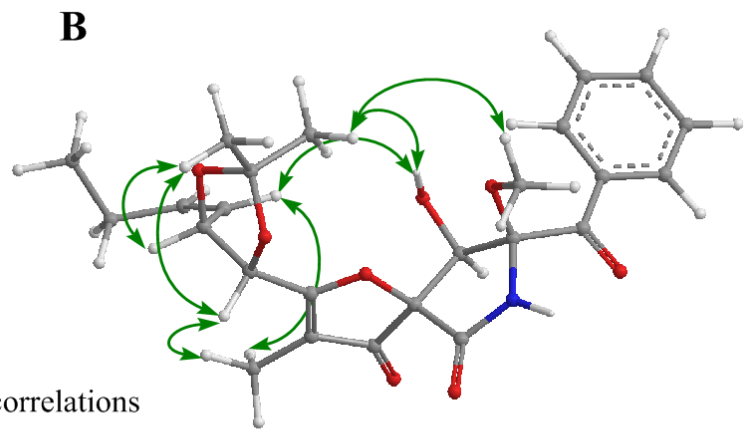

7

Figure 4. Key NOESY correlations of acetonide derivatives 6 (A) and 7 (B).

\section{Experimental Section}

\subsection{General Experimental Procedures}

UV spectra were recorded on a Shimadzu (Kyoto, Japan) spectro-photometer U-2000 and IR spectra on a JASCO (Tokyo, Japan) FT/IR-680 Plus. NMR spectra were recorded at $27^{\circ} \mathrm{C}$ on Agilent (Santa Clara, CA, USA) NMR-vnmrs600 with tetramethylsilane (TMS) (Nacalai Tesque Inc., Kyoto, Japan) as an internal reference. Mass spectra were determined using a Hitachi M- $4000 \mathrm{H}$ mass spectrometer. Optical rotatory dispersion (ORD) were recorded on a JASCO J-820 polarimeters. Liquid chromatography over silica gel (mesh 230-400) was performed at a medium pressure. HPLC was run on a JASCO PU-1586 equipped with a differential refractometer (RI-1531) and Cosmosil Packed Column 5C 18 -MSII $(25 \mathrm{~cm} \times 20 \mathrm{~mm}$ i.d.) (Kyoto, Japan). Analytical TLC was performed on precoated Merck (Darmstadt, Germany) aluminum sheets (DC-Alufolien Kieselgel 60 F254, $0.2 \mathrm{~mm}$ ) with the solvent system $\mathrm{CH}_{2} \mathrm{Cl}_{2}-\mathrm{MeOH}$ (19:1), and compounds were viewed under UV lamp and sprayed with $10 \% \mathrm{H}_{2} \mathrm{SO}_{4}$ followed by heating.

\subsection{Fungal Material}

A strain of A. fumigatus was initially isolated from the marine fish Mugil cephalus captured in Katsuura Bay, Japan, in October 2000. The fish was disinfected with EtOH and its gastrointestinal tract applied to the surface of nutrient agar layered in a Petri dish. Serial transfers of one of the resulting 
colonies provided a pure strain of $A$. fumigatus. The fungal strains were identified by Techno Suruga Laboratory Co., Ltd. (Shizuoka, Japan).

\subsection{Culturing and Isolation of Metabolites}

The fungal strain was cultured at $27^{\circ} \mathrm{C}$ for six weeks in a liquid medium $(75 \mathrm{~L})$ containing $1 \%$ soluble starch and $0.1 \%$ casein in $50 \%$ artificial seawater adjusted to $\mathrm{pH} 7.4$. The culture was filtered under suction, and the culture filtrate was extracted three times with EtOAc. The combined extracts were evaporated in vacuo to afford a mixture of crude metabolites $(20.5 \mathrm{~g})$ that exhibited cytotoxicity against the P388 cell line $\left(\mathrm{IC}_{50}<1 \mu \mathrm{g} / \mathrm{mL}\right)$. The EtOAc extract was passed through a Sephadex LH-20 column using $\mathrm{CHCl}_{3}-\mathrm{MeOH}(1: 1)$ as the eluent. The second fraction (13.8 g) was chromatographed on a silica gel column with a hexane- $\mathrm{CHCl}_{3}-\mathrm{MeOH}$ gradient as the eluent to afford Fr. 1 (the $2 \% \mathrm{MeOH}$ in $\mathrm{CHCl}_{3}$ eluate, $3.6 \mathrm{~g}$ ). Fr. 1 was chromatographed on a silica gel column with a $\mathrm{CHCl}_{3}-\mathrm{MeOH}$ gradient as the eluent to afford Fr. 2 (the $5 \% \mathrm{MeOH}$ in $\mathrm{CHCl}_{3}$ eluate, $1.4 \mathrm{~g}$ ). Fr. 2 was purified by HPLC using $\mathrm{MeOH}-\mathrm{H}_{2} \mathrm{O}(70: 30)$ as the eluent to afford Fr. $3(247.9 \mathrm{mg})$ and Fr. $4(45.6 \mathrm{mg})$. Fr. 3 was purified by HPLC using $\mathrm{MeOH}-\mathrm{H}_{2} \mathrm{O}$ (50:50) as the eluent to afford Fr. 5 (168.4 mg). Fr. 5 was purified by ODS HPLC using $\mathrm{MeCN}-\mathrm{H}_{2} \mathrm{O}$ (30:70) as the eluent to afford pseurotin $\mathrm{A}_{1}(\mathbf{1}, 1.5 \mathrm{mg})$ and pseurotin $\mathrm{A}$ $(3,70.5 \mathrm{mg})$. Fr. 4 was purified by HPLC using $\mathrm{MeOH}-\mathrm{H}_{2} \mathrm{O}$ (50: 50) as the eluent to afford Fr. 6 (168.4 mg). Fr. 6 was purified by ODS HPLC using $\mathrm{MeCN}-\mathrm{H}_{2} \mathrm{O}$ (30:70) as the eluent to afford pseurotin $\mathrm{A}_{2}(4,4.1 \mathrm{mg})$.

Pseurotins $A, A_{1}$ and $A_{2}:{ }^{1} \mathrm{H}$ - and ${ }^{13} \mathrm{C}-\mathrm{NMR}$ data $\left(\mathrm{CDCl}_{3}\right)$ are listed in Table 1.

\subsection{Chemical Transformation}

\subsubsection{Epimerization of 3}

To a solution of $3(3.2 \mathrm{mg})$ in $\mathrm{MeOH}(0.5 \mathrm{~mL})$, one drop of conc. $\mathrm{H}_{2} \mathrm{SO}_{4}$. was added, and the reaction mixture was stirred at room temperature for $30 \mathrm{~min}$. The reaction mixture was extracted with diethyl ether thrice, and the organic layer was evaporated under reduced pressure. The residue was purified by $\mathrm{HPLC}$ using $\mathrm{MeCN}-\mathrm{H}_{2} \mathrm{O}$ (30:70) as the eluent to afford 5 (0.6 mg).

\subsubsection{Derivatization to Acetonides from Pseurotin $A_{1}(\mathbf{1})$ and $A_{2}(4)$}

To a solution of $\mathbf{1}(3.3 \mathrm{mg})$ in $\mathrm{CH}_{2} \mathrm{Cl}_{2}(0.3 \mathrm{~mL})$, 2,2-dimethoxypropane $(0.3 \mathrm{~mL})$ and pyridium p-toluensulfonate $(0.2 \mathrm{mg})$ were added, and the reaction mixture was stirred at room temperature for $1 \mathrm{~h}$. The reaction mixture was evaporated under reduced pressure. The residue was purified by HPLC using $\mathrm{MeOH}-\mathrm{H}_{2} \mathrm{O}(60: 40)$ as the eluent to afford acetonide 6 (2.2 $\left.\mathrm{mg}\right)$. Using the same procedure, 4 $(2.0 \mathrm{mg})$ was treated with 2,2-dimethoxypropane $(0.3 \mathrm{~mL})$ and pyridium $p$-toluensulfonate $(0.2 \mathrm{mg})$, and purified by HPLC to afford 7 (0.4 mg).

Acetonide 6: Pale yellow oil; FABMS $m / z$ (rel. int.): HRFABMS $m / z 472.1964[\mathrm{M}+\mathrm{H}]^{+}$ (calcd for $\mathrm{C}_{25} \mathrm{H}_{30} \mathrm{NO}_{8}$ : 472.1970). ${ }^{1} \mathrm{H}-\mathrm{NMR} \delta \mathrm{ppm}\left(\mathrm{CDCl}_{3}\right): 0.95(3 \mathrm{H}, \mathrm{t}, J=7.2 \mathrm{~Hz}, \mathrm{H}-15), 1.43$ $\left(3 \mathrm{H}, \mathrm{s}\right.$, acetonide- $\left.\beta-\mathrm{CH}_{3}\right), 1.58\left(3 \mathrm{H}, \mathrm{s}\right.$, acetonide- $\left.\alpha-\mathrm{CH}_{3}\right), 1.73(3 \mathrm{H}, \mathrm{s}, \mathrm{H}-16), 2.04(1 \mathrm{H}, \mathrm{m}, \mathrm{H}-14 \mathrm{~A}), 2.17$ (1H, m, H-14B), $2.76(1 \mathrm{H}, \mathrm{d}, J=3.6 \mathrm{~Hz}, 9-\mathrm{OH}), 3.31\left(3 \mathrm{H}, \mathrm{s}, 9-\mathrm{OCH}_{3}\right), 4.77(1 \mathrm{H}, \mathrm{d}, J=3.6 \mathrm{~Hz}, \mathrm{H}-9), 5.15$ $(1 \mathrm{H}, \mathrm{d}, J=7.8 \mathrm{~Hz}, \mathrm{H}-10), 5.25(1 \mathrm{H}, \mathrm{ddd}, J=9.6,7.8,1.2 \mathrm{~Hz}, \mathrm{H}-11), 5.57(1 \mathrm{H}, \mathrm{ddt}, J=10.8,9.6,1.2 \mathrm{~Hz}$, H-12), 5.57 (1H, dtd, $J=10.8,7.2,1.2 \mathrm{~Hz}, \mathrm{H}-13), 7.33(1 \mathrm{H}, \mathrm{br} \mathrm{s}, \mathrm{H}-6), 7.43$ (2H, t, $J=7.8 \mathrm{~Hz}, \mathrm{H}-20$ and $\mathrm{H}-22), 7.66(1 \mathrm{H}, \mathrm{t}, J=7.8 \mathrm{~Hz}, \mathrm{H}-21), 8.22(2 \mathrm{H}, \mathrm{d}, J=7.8 \mathrm{~Hz}, \mathrm{H}-19$ and $\mathrm{H}-23)$.

Acetonide 7: Pale yellow oil; FABMS $m / z$ (rel. int.): HRFABMS $m / z 472.1964[\mathrm{M}+\mathrm{H}]^{+}$(calcd for $\mathrm{C}_{25} \mathrm{H}_{30} \mathrm{NO}_{8}$ : 472.1970). ${ }^{1} \mathrm{H}-\mathrm{NMR} \delta \mathrm{ppm}\left(\mathrm{CDCl}_{3}\right): 1.02(3 \mathrm{H}, \mathrm{t}, J=7.2 \mathrm{~Hz}, \mathrm{H}-15), 1.49(3 \mathrm{H}, \mathrm{s}$, acetonide- $\left.\beta-\mathrm{CH}_{3}\right), 1.64\left(3 \mathrm{H}, \mathrm{s}\right.$, acetonide- $\left.\alpha-\mathrm{CH}_{3}\right), 1.67(3 \mathrm{H}, \mathrm{s}, \mathrm{H}-16), 2.13(1 \mathrm{H}, \mathrm{m}, \mathrm{H}-14 \mathrm{~A}), 2.20(1 \mathrm{H}, \mathrm{m}$, H-14B), $3.29\left(3 \mathrm{H}, \mathrm{s}, 9-\mathrm{OCH}_{3}\right), 3.36(1 \mathrm{H}, \mathrm{d}, J=12.6 \mathrm{~Hz}, 9-\mathrm{OH}), 4.52(1 \mathrm{H}, \mathrm{d}, J=12.6 \mathrm{~Hz}, \mathrm{H}-9), 5.17(1 \mathrm{H}, \mathrm{d}$, $J=6.6 \mathrm{~Hz}, \mathrm{H}-10), 5.26(1 \mathrm{H}, \mathrm{ddd}, J=9.0,6.6,1.2 \mathrm{~Hz}, \mathrm{H}-11), 5.57(1 \mathrm{H}, \mathrm{ddt}, J=10.8,9.0,1.2 \mathrm{~Hz}, \mathrm{H}-12)$, $5.72(1 \mathrm{H}, \mathrm{dtd}, J=10.8,7.2,0.6 \mathrm{~Hz}, \mathrm{H}-13), 7.49(2 \mathrm{H}, \mathrm{t}, J=7.8 \mathrm{~Hz}, \mathrm{H}-20$ and H-22), $7.64(1 \mathrm{H}, \mathrm{t}, J=7.8 \mathrm{~Hz}$, $\mathrm{H}-21), 8.29$ (2H, d, J = 7.8 Hz, H-19 and H-23). 


\section{Conclusions}

Q.Q. Gu et al. [14] deduced the stereostructure of pseurotin $A_{2}$ as 2 from NOESY experiments and a comparison of CD spectra with cephalimysins. We assigned the CD Cotton effect ascribed to the absolute configuration at C-8 by the epimerization of pseurotin A (3), and revised the stereostructure of pseurotin $A_{2}$ from 2 to 4 . In this process, we newly found the Cotton effect ascribed to the absolute configuration at C-5. In addition, we found that the absolute configuration in the side chain of pseurotins could be established positively by detailed analyses of the NOESY experiments of their acetonide derivatives.

Supplementary Materials: The following are available online at www.mdpi.com/1660-3397/14/4/74/s1,

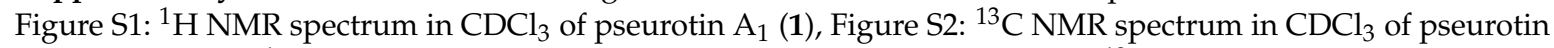
$\mathrm{A}_{1}$ (1), Figure S3: ${ }^{1} \mathrm{H}$ NMR spectrum in $\mathrm{CDCl}_{3}$ of pseurotin $\mathrm{A}_{2}(4)$, Figure $\mathrm{S} 4:{ }^{13} \mathrm{C}$ NMR spectrum in $\mathrm{CDCl}_{3}$ of pseurotin $A_{2}(4)$, Figure S5: 2D NMR spectra of pseurotin $A_{2}(4)\left({ }^{1} \mathrm{H}^{-1} \mathrm{H}\right.$ COSY), Figure S6: 2D NMR spectra of pseurotin $\mathrm{A}_{2}$ (4) (HMQC), Figure S7: 2D NMR spectra of pseurotin $\mathrm{A}_{2}$ (4) (HMBC), Figure S8: ${ }^{1} \mathrm{H}$ NMR spectrum in $\mathrm{CDCl}_{3}$ of pseurotin $\mathrm{A}$ (3), Figure S9: ${ }^{13} \mathrm{C} \mathrm{NMR}$ spectrum in $\mathrm{CDCl}_{3}$ of pseurotin $\mathrm{A}(3)$, Figure S10: ${ }^{1} \mathrm{H} \mathrm{NMR}$ spectrum in $\mathrm{CDCl}_{3}$ of pseurotin A (3) (400 MHz), Figure S11: ${ }^{1} \mathrm{H}$ NMR spectrum in $\mathrm{CDCl}_{3}$ of 5 (8-epimer of 3), Figure S12: ${ }^{13} \mathrm{C}$ NMR spectrum in $\mathrm{CDCl}_{3}$ of 5 (8-epimer of 3), Figure S13: ${ }^{1} \mathrm{H}$ NMR spectrum in $\mathrm{CDCl}_{3}$ of 6 (acetonide of 1), Figure S14: ${ }^{1} \mathrm{H}$ NMR spectrum in $\mathrm{CDCl}_{3}$ of 7 (acetonide of 4), Figure S15: NOESY of 6 (acetonide of 1), Figure S16: NOESY of 7 (acetonide of 4).

Acknowledgments: We are grateful to M. Fujitake and K. Minoura of this university for MS and NMR measurements, respectively. This study was supported by JSPS KAKENHI Grant Number 26460136.

Author Contributions: Conceived and designed the experiments: Mina Ohshima, Kaori Yuasa, Reiko Tanaka, Takashi Kikuchi, Takeshi Yamada; Performed the experiments: Mina Ohshima, Kaori Yuasa, Takeshi Yamada; Analyzed the data: Takeshi Yamada; Wrote the paper: Takeshi Yamada.

Conflicts of Interest: The authors declare no conflict of interest.

\section{References}

1. Bloch, P.; Tamm, C.; Bollinger, P.; Petcher, T.J.; Weber, H.P. Pseurotin, a New Metabolite of Pseudeurotium ovalis STOLK Having an Unusual Hetero-Spirocyclic System. Helv. Chim. Acta 1976, 59, 133-137. [CrossRef] [PubMed]

2. Weber, H.P.; Petcher, T.J.; Bloch, P.; Tamm, C. The Crystal and Molecular Structure of 12, 13-Dibromopseurotin. Helv. Chim. Acta 1976, 59, 137-140. [CrossRef] [PubMed]

3. Bloch, P.; Tamm, C. Isolation and Structure of Pseurotin A, a Microbial Metabolite of Pseudeurotium ovalis STOLK with an Unusual Heterospirocyclic System. Helv. Chim. Acta 1981, 64, 304-315. [CrossRef]

4. Ishikawa, M.; Ninomiya, T.; Akabane, H.; Kushida, N.; Tsujiuchi, G.; Ohyama, M.; Gomi, S.; Shito, K.; Murata, T. Pseurotin A and its analogues as inhibitors of immunoglobuline E production. Bioorg. Med. Chem. Lett. 2009, 19, 1457-1460. [CrossRef] [PubMed]

5. Hayashi, Y.; Shoji, M.; Yamaguchi, J.; Sato, K.; Yamaguchi, S.; Mukaiyama, T.; Sakai, K.; Asami, Y.; Kakeya, H.; Osada, H. Asymmetric Total Synthesis of (-)-Azaspirene, a Novel Angiogenesis Inhibitor. J. Am. Chem. Soc. 2002, 124, 12078-12079. [CrossRef] [PubMed]

6. Aoki, S.; Oi, T.; Shimizu, K.; Shiraki, R.; Takao, K.; Tadano, K. Total Syntheses of Natural Pseurotins A, $F_{2}$, and Azaspirene. Bull. Chem. Soc. Jpn. 2004, 77, 1703-1716. [CrossRef]

7. Hayashi, Y.; Shoji, M.; Yamaguchi, S.; Mukaiyama, T.; Yamaguchi, J.; Kakeya, H.; Osada, H. Asymmetric Total Synthesis of Pseurotin A. Org. Lett. 2003, 5, 2287-2290. [CrossRef] [PubMed]

8. Hayashi, Y.; Shoji, M.; Mukaiyama, T.; Gotoh, H.; Yamaguchi, S.; Nakata, M.; Kakeya, H.; Osada, H. First Asymmetric Total Synthesis of Synerazol, an Antifungal Antibiotic, and Determination of Its Absolute Stereochemistry. J. Org. Chem. 2005, 70, 5643-5654. [CrossRef] [PubMed]

9. Orellana, A.; Rovis, T. Towards the total synthesis of FD-838: Modular enantioselective assembly of the core. Chem. Commun. 2008, 730-732. [CrossRef]

10. Hayashi, Y.; Sankar, K.; Ishikawa, H.; Nozawa, Y.; Mizoue, K.; Kakeya, H. Total synthesis and determination of the absolute configuration of FD-838, a naturally occurring azaspirobicyclic product. Bioorg. Med. Chem. Lett. 2009, 19, 3863-3865. [CrossRef] [PubMed] 
11. Igarashi, Y.; Yabuta, Y.; Furumai, T. Determination of the absolute configuration of synerazol. J. Antibiotics 2004, 57, 537-540. [CrossRef]

12. Yamada, T.; Imai, E.; Nakatsuji, K.; Numata, A.; Tanaka, R. Cephalimysin A, a potent cytotoxic metabolite from an Aspergillus species separated from a marine fish. Tetrahedron Lett. 2007, 48, 6294-6296. [CrossRef]

13. Yamada, T.; Kitada, H.; Kajimoto, T.; Numata, A.; Tanaka, R. The Relationship between the CD Cotton Effect and the Absolute Configuration of FD-838 and Its Seven Stereoisomers. J. Org. Chem. 2010, 75, 4146-4153. [CrossRef] [PubMed]

14. Wang, F.Z.; Li, D.H.; Zhu, T.J.; Zhang, M.; Gu, Q.Q. Pseurotin $\mathrm{A}_{1}$ and $\mathrm{A}_{2}$, two new 1-oxa-7-azaspiro[4.4]non-2-ene-4,6-diones from the holothurian-derived fungus Aspergillus fumigatus WFZ-25. Can. J. Chem. 2011, 89, 72-76. [CrossRef]

(C) 2016 by the authors; licensee MDPI, Basel, Switzerland. This article is an open access article distributed under the terms and conditions of the Creative Commons Attribution (CC-BY) license (http:/ / creativecommons.org/licenses/by/4.0/). 